\title{
Trabalho, ócio, preguiça: cumpre imaginar Sísifo feliz!
}

\author{
Labour, idleness, laziness: one must imagine Sisyphus happy!
}

\author{
Antônio José Romera Valverde*
}

Pontifícia Universidade Católica de São Paulo, São Paulo, SP, Brasil

"Les dieux avaient condamné Sisyphe à rouler sans cesse un rocher jusqu'au sommet d'une montagne d'où la pierre retombait par son propre poids. Ils avaient pensé avec quelque raison qui'il n'est pas de punition plus terrible que le travail inutile et sans espoir." (Albert Camus, Le Mythe de Sisyphe) ${ }^{1}$

1 CAMUS, 2008, p. 163.

A propósito, Marcuse comentou: 'As páginas seguintes tratam do sentimento de absurdidade, que predomina em nosso mundo'. Esta sentença inicial de 0 mito de Sísifo (Le Mythe de Sisyphe), de Albert Camus, expressa o clima no qual o existencialismo se origina. Camus não pertence à escola existencialista, porém, a experiência fundamental que permeia seu pensamento também está na raiz do existencialismo. É a época do terror totalitário: 0 regime nazista está no auge de seu poder; a França está ocupada por tropas alemãs. Os valores e as normas da civilização ocidental estão coordenados e substituídos pela realidade (Wirklichkeit) do sistema fascista. Mais uma vez o pensamento é devolvido a si mesmo por uma realidade que contradiz todas as promessas e ideias, que refuta tanto o racionalismo quanto a religião, tanto o idealismo quanto o materialismo. [...] 0 mito de Sísifo, de Camus, retoma 0 clima da filosofia de Nietzsche: '0 homem do absurdo entrevê um universo ardente e gelado, transparente e limitado, onde nada é possível senão tudo é dado, além do qual é 0 aniquilamento e o nada"' MARCUSE, H. 0 Existencialismo. In: MARCUSE, 1998, p. 51-52. (A rigor, a sentença inicial citada por Marcuse é: "Les pages qui suivent traitent d'une sensibilité absurde qu'on peut trouver éparse das le siècle..... CAMUS, 2008, p. 16). Para a referência a Nietzsche, conferir CAMUS, 2008, p. 85.

*AJRV: Doutor em Filosofia, e-mail: ajrvalverde@uol.com.br

Rev. Filos., Aurora, Curitiba, v. 30, n. 50, p. 424-449, maio/ago. 2018 


\section{Resumo}

O ensaio explora aspectos do trabalho humano, fundando-se em contribuições teóricas e remissões à Literatura, de modo a levar águas aos moinhos da heresia firmada contra o trabalho, na linha do elogio crítico e do ataque às apologias mais renitentes. Analisa os nexos entre trabalho, ócio, preguiça e, no limite, ética e política. Sem perder de vista o horizonte histórico do problema.

Palavras-chave: Trabalho. Ócio. Preguiça. Marcuse. Civilização libidinal. Ética. Brasil.

\section{Abstract}

The essay explores issues concerning human labour under theoretical frameworks and literature apologies aiming at leading into a quixotic fight in the windmills of heresy against labour. A fight in line with a critical compliment, therefore combating the most persistent apologies. It analyses existing causal nexus between labour, idleness, laziness, and to the limits of ethics and politics. Having in sight the problem under its historical perspective.

Keywords: Labour. Idleness. Laziness. Marcuse. Libidinal civilization. Ethics. Brazil.

Se "[...] não há castigo mais terrível do que o trabalho inútil e sem esperança", ainda para Camus, de tempos em tempos os mitos são criados para que a imaginação os anime. Assim, o elogio desconfiado do trabalho (HESÍODO, 2012, p. 308-319) $)^{2}$ e a discussão acerca da espera do cumprimento da

\footnotetext{
2 Eis os versos ilustrativos do elogio desconfiado do trabalho:

"Por sus trabajos, los hombres son ricos en greyes y en bienes;

y, trabajando, mucho más a los inmortales querido

[serás y a los hombres: pues mucho a los ociosos detestan.] (310)

El trabajo, ninguna deshonra; el ocio es deshonra;

y si trabajas te envidiará pronto, porque te enriqueces,

el ocioso; a la riqueza mérito y gloria acompañan.

Según cual eres por suerte, el trabajar es mejor,

si, de los bienes ajenos la mente insensata (315)

volviendo al trabajo, del sustento cuidas - como te exhorto.
} 
Justiça (HESÍODO, 2012, p. 202-285) viajam no tempo há dois mil e setecentos anos, aproximadamente, desde Os Trabalhos e os Dias, de Hesíodo, poema inspirado ao poeta pastor pelas $\mathrm{Musas}^{3}$, no sopé do monte Hélicon. Em verdade, o poema retrata a ordem do mundo dos mortais e da própria condição humana, de suor e de riqueza, à expectação da justiça, em contraposição e complementaridade a outro poema do mesmo poeta inspirado, Teogonia, a espelhar a genealogia dos deuses, as disputas de poder e as partilhas de atributos entre eles. Vez que os deuses gregos são imagem e semelhança das paixões dos mortais...

Pico della Mirandola, sob o arco filosófico do humanismo renascentista, provavelmente tenha sido o primeiro filósofo a conceber o homem como homo faber, sob chave inaugural da pré-Modernidade, provendo o movimento em curso de desacorrentar Prometeus. Em Oratio de Hominis Dignitate, de 1486, afirma que o homem não tem sede própria na natureza, nem é um ser determinado desde a criação como os animais e a milícia celeste, por isto pode autocriar-se, autoprojetar-se e fazer de si o que lhe aprouver, de modo a deixar a marca de liberdade pessoal na linha de (re)criação de si por si, diferentemente do que ocorre com os todos os outros seres da sempiterna natureza ${ }^{4}$. $\mathrm{O}$ homem compõe parte da natureza, porém, pode se autodeterminar. No limite, quiçá, o homem pode moldar a história à sua imagem e semelhança. Afinal, como reconhece Agnes Heller, o entender-se como produto e produtor da história tem sido uma das heranças, ora latente ora a caminho de explicitação, do humanismo renascentista.

Contudo, a meados do século XVIII, Vico anteviu que o excesso de racionalidade de par com a matematização da natureza - dos primórdios da Modernidade - reconduziria a humanidade à barbárie. Assim,

\footnotetext{
Vergüenza no buena al hombre indigente acompaña, vergüenza que asaz perjudica o favorece a los hombres; vergüenza en la pobreza, y audacia en la dicha." (HESÍOD0, Los Trabajos y los Dias, 2007, p. 309-319) 3 "Musas da Pieria, que dais con los cantos la gloria, (1) aquí hablad de Zeus, a vuestro padre honrado con himnos, por el cual los hombres mortales, sin fama igual que afamados, notos e ignotos son, por voluntad del gran Zeus."

(HESÍOD0, Idem, p. 1-4)

4 A propósito, conferir VALVERDE, 2009, p. 457-480.
} 
a racionalidade tem pautado, no detalhe, a cultura moderna e, aceleradamente, a civilização tecnológica contemporânea. Sob tal contexto, as relações entre trabalho e ética apresentam-se como forças em tensão, por hipótese, devida à excessiva crença no trabalho como horizonte gerador de riqueza e de razoável controle social. Afinal, se o trabalho foi considerado a melhor polícia, na atualidade, novas formas de controle tecnológico ocuparam seu lugar, por certo com mais eficiência, para desatino da humanidade, sob a égide da "euforia na infelicidade".

A um tempo em que a norma ética universal, construída desde Aristóteles e pela tradição medieval, cedia lugar à profusão de discursos éticos modernos, no mesmo passo em que o espectro dinâmico do projeto burguês tendia a impor-se de modo hegemônico, Giacomo Leopardi, ao início do século XIX, reconhecera o desenlace do ethos antigo e o caminhar a passos largos da civilização para uma nova onda de barbárie, sobremaneira em Discurso sobre o estado atual dos costumes dos italianos ${ }^{5}$, dentre outros escritos. Se de fato a barbárie se impôs como reconhecem os filósofos frankfurtianos, ética e trabalho apresentam-se como duas forças tencionadas, porém, enfraquecidas, e em disputa permanente, como simulacros de ambas. Ao passo que o projeto burguês se balizou pela autonomia da razão, progresso econômico e "dignidade" do trabalho, em vista da acumulação infinita de riquezas, diferenciou-se do passado em que o trabalho físico não atingia reconhecimento social.

Se na Antiguidade houve um desprestígio inquestionável do trabalho manual, como atributo de escravo, na Idade Média, do naturalmente escravo, e, mesmo no Novo Testamento, as figuras de Maria e Marta rivalizam entre si o ascender ao espírito e à vida de tarefas rotineiras, ao tempo da inserção e do desenvolvimento do projeto burguês, parte essencial de seu progresso deu-se pela valorização do trabalho, sobremaneira, na figura emblemática do engenheiro ${ }^{6}$, profissional capaz de aliar teoria e técnica a um só tempo - a

5 LEOPARDI, G. Discurso sobre o estado atual dos costumes dos italianos. Trad. Vera Horn. In: LEOPARDI, 1996, p. 523-548. Ver também, LEOPARDI, 2014. A propósito, conferir TEIXEIRA, 2013.

6 "Observe-se que, com a revolução industrial, surge a figura do engenheiro, esse ser duplo que associa a destreza das mãos artesanais ao apurado cálculo da nova ciência da natureza; não há exagero em afirmar que 0 advento do engenheiro constitui o primeiro grande golpe que sofre a antiga e dominadora definição do homem, introduzida pelos gregos — 0 animal racional —, e que repousa na dissociação, peculiar a toda cultura ocidental, entre a teoria e a práxis, entre os homens 
valorizar o trabalho como tarefa burguesa essencial. Assim, ao fundir num só trabalhador a teoria e a técnica, o projeto burguês mostrou pela primeira vez na história que a classe social, que viria a dinamizar o mundo em todos os sentidos, valorizava o trabalho sem dissimulações. Contudo, a fragmentação e a segmentação éticas, ocorridas de par com o desenvolvimento e a realização do projeto burguês, refletiram, em parte, a desvalorização do trabalho como essência humana, seja pela automação atual da indústria, seja pela excessiva especialização técnica e das habilidades dos trabalhadores, tendo como cenário a expansão sem controle da tecnociência e da imediata aplicabilidade técnica de pesquisas científicas pré-direcionadas.

Em contraponto ao sucesso do projeto burguês, - intermediado pelo humanista renascentista cristão, Thomas More, que não dispensa nem o trabalho, diga-se, tradicional nem o trabalho escravo, na invenção da sociedade utópica (moderna) - , o comentário histórico de Sérgio Buarque de Holanda, de inspiração weberiana, mostra-se extensivo para compreensão do problema da divisão do trabalho:

A produção em larga escala, a organização de grandes massas de trabalho e complicados mecanismos para colossais rendimentos, acentuou, aparentemente, e exacerbou a separação das classes produtoras, tornando inevitável um sentimento de irresponsabilidade, da parte dos que dirigem, pelas vidas dos trabalhadores manuais. Compare-se o sistema de produção, tal como existia quando o mestre e seu aprendiz ou empregado trabalhavam na mesma sala e utilizavam os mesmos instrumentos, com o que ocorre na organização habitual da corporação moderna. No primeiro, as relações de empregador e empregado eram pessoais e diretas, não havia autoridades intermediárias. Na última, o trabalhador manual e o derradeiro proprietário - o acionista - existe toda uma hierarquia de funcionários e autoridades representados pelo superintendente da usina, o diretor-geral, o presidente da corporação, a junta executiva do conselho de diretoria e o próprio conselho de diretoria. Como é fácil que a responsabilidade por acidentes do trabalho, salários inadequados ou condições anti-higiênicas se perca de um extremo ao outro dessa série (HOLANDA, 2006, p. 155)7

de pensamento e 0 artesão. Reforça-se, por aí, aquela autonomia instauradora do homem burguês." BORNHEIM, G. O Sujeito e a Norma. In: NOVAES, 1992, p. 250.

7 A meados do século XVIII, Adam Smith reputara o "desenvolvimento da produtividade do trabalho, e o aumento do engenho, destreza e discernimento ao qual está ligado", ao que "parece ter sido provocado pela divisão do trabalho"(SMITH, 1974, p. 13). Pois, a "divisão do 
Sob o exercício prático e extensivo do ócio filosófico, pleno de reflexões, análises e desmontes radicais do ideário moderno, Nietzsche, no aforismo 173, de Aurora, intitulado "Os apologistas do trabalho", problematiza o trabalho para além da maldição ontológica, aquela derivada das primeiras páginas do Gênesis, quiçá a antecipar a sociedade de controle da atualidade. A propósito, Nietzsche escreveu:

Na glorificação do "trabalho", nos infatigáveis discursos da "bendição do trabalho", vejo a mesma segunda intenção que nos elogios dos atos impessoais e de um interesse geral: a reserva do temor a tudo quanto é individual. Dá-se agora exata compreensão ao aspecto do trabalho quer dizer, a essa dura atividade da manhã à noite - que é a melhor polícia, que traz cada um de nós pela rédea e que sabe impedir vigorosamente o desenvolvimento da razão, da concupiscência, dos desejos de independência. Pois, o trabalho desgasta a força nervosa em proporções extraordinárias, retira esta força da reflexão, da meditação, dos sonhos, do amor e do ódio, põe sempre ante os olhos um fim mínimo e concede satisfações fáceis e regulares. Assim, uma sociedade, na qual se trabalha incessantemente, gozará de uma maior segurança: e esta é a segurança que hoje se admira como divindade suprema, E eis aqui (é espantoso!) que justamente o "trabalhador" é quem se tornou perigoso. Os "indivíduos perigosos" formigueiam! E atrás deles há o perigo dos perigos: o "individuum" (NIETZSCHE, 1947, aforismo 173, p. 113-114).

Tratar dos direitos e de sua ciência, que se funda na opinião dos povos e nos costumes das nações civis, é praticamente impossível se não se levar em conta um elemento, ora vislumbrado ora ocultado da Modernidade até os dias correntes, pois desde o início da Idade Moderna existe um ponto cego no universo das relações sociais: a apologia do trabalho, com ou sem uma ontologia de suporte. Antes mesmo da crítica

trabalho, da qual derivam tantas vantagens, não originalmente provocada pelo gênio humano, prevendo com intencionalidade a riqueza que ela viria a proporcionar", porém, teria sido "a consequência necessária, se bem que lenta e gradual, de uma determinada tendência da natureza humana que tem como objetivo uma utilidade menos extensiva: a tendência para negociar e trocar uma coisa por outra" (SMITH, 1974, p. 19). Tais concepções foram objeto de crítica por Marx, nos Manuscritos Econômicos-Filosóficos.

8 Poderá "0 'individuum"' apontado por Nietzsche aproximar-se de algum modo da noção de "indivíduo soberano", constante da "II Dissertação", de A Genealogia da Moral? A propósito da noção de "indivíduo soberano", em Nietzsche, ver GIACOIA JUNIOR, 0. Nietzsche: 0 humano como memória e como promessa. 2. ed. Petrópolis: Vozes, 2013, p. 111-114. 
weberiana à ética protestante e seu nexo com o espírito do capitalismo cuja disposição em ordem inversa seria mais correta - Lutero facilitara a entrada em cena dessa novidade. Ao que Nietzsche registrou:

O mais importante que fez Lutero foi ter despertado a desconfiança a respeito dos santos e da vita contemplativa em geral: só a partir de sua época se tornou possível na Europa o caminho que conduz de uma vita contemplativa não cristã e foi posto um freio ao menosprezo que inspirava a atividade leiga. Lutero permaneceu um bravo filho de mineiro, quando foi encerrado num convento, na falta de outras profundidades e outros "filões", desceu em si mesmo para abrir aí terríveis galerias subterrâneas. Lutero notou afinal que uma vida sã e contemplativa lhe era impossível e que a "atividade" que possuía de nascimento lhe minaria corpo e alma (NIETZSCHE, 1947, aforismo 88, p. 59).

Nietzsche conclui a reflexão citando o próprio Lutero “"Fora dos dez mandamentos, não há obras que possam agradar a Deus; as obras espirituais, tão louvadas pelos santos, são puramente imaginárias" (NIETZSCHE, 1947, aforismo 88, p. 60).

Acaso seria o fim do tédio indolente (accidia) da vita contemplativa sob o teto do dinamismo inédito do projeto burguês? Ou a índole religiosa estivera em movimento de perder terreno para a índole desbravadora, pragmática, votada aos atos de dissecar, medir, quantificar e, no limite, operacionalizar o conhecimento da natureza física externa ao homem e por extensão também a natureza humana, de bem com os ventos dos novos tempos pela invenção da ciência moderna, sob o escopo do projeto baconiano e da matematização da natureza, por Newton? Despontando até o fastio - l'ennui, a incuriosidade baudelairiana - do homem contemporâneo, pelo niilismo, a fórmula do entendimento de Nietzsche acerca do arremate dos tédios, medieval e contemporâneo: de Deus e do homem; o fastio medieval de Deus e o fastio contemporâneo do homem. Assim, Lutero, outrora monge agostiniano, abrira a Modernidade concluindo o que Cícero e os humanistas cívicos florentinos sabiam, sobejamente: a vita activa tornara-se 
superior à vita contemplativa ${ }^{9}$ ? - Na forma negócio-política, sob o arco do ateísmo prático. Com a ressalva ciceroniana: "mais trabalho quando não faço nada!" , em defesa do ócio sem adjetivos.

A Era Contemporânea, em parte expressiva devido à compreensão de Marx, só fez reforçar o valor do trabalho desde a concepção de trabalho abstrato, tomando-o como uma essência supra histórica do homem, como teleologia do trabalho, balizado ainda pela noção liberal de progresso e pela concepção da evolução biológica, posto em movimento pela encarnação do tempo histórico, linear ascendente. Mas, com que finalidade? Tanto o universo burguês, centenariamente instituído, quanto o "socialismo real existente", - expressão criada por Rudolf Bahro - , do século passado não fizeram senão a eloquente apologia do trabalho, porém, diferentemente do conceito de trabalho abstrato, porquanto o trabalho desde os primórdios da Modernidade transformou-se em fim de si mesmo. Esta armadilha foi aditada e alimentada pela instrumentalização do saber, desde Francis Bacon, transmutada na possibilidade de aplicabilidade técnica dos modelos ideais da ciência. Logo, com possibilidade de transformação em poder, poder real e não simbólico, pois, "ciência e poder do homem coincidem [...]" (BACON, 1979, p. 13), vaticinara o Barão de Verulamo. No presente, os termos tecnociência e tecnologia, derivados para detalhamento específico da pesquisa científica aplicada, como também a tecnobiologia, circunscrevem o progresso das ciências e, por extensão, a ambientação do aspecto ético das consequências imprevisíveis do "Prometeu desacorrentado" desde o século XVII, como pensa Hans Jonas ${ }^{10}$.

9 A propósito do "ócio ativo" de Cícero, conferir BARON, H. La Relembranza del Espíritu Cívico Romano de Cicerón a lo largo de lós Siglos Medievales y em El Renacimiento Florentino. In: BARON, H. En Busca del Humanismo Civico Florentino. Ensayos sobre el Cambio del Pensamiento Medieval al Moderno. Trad. Miguel Abelardo Camacho Ocampo. México: Fondo de Cultura Económica, 1993, p. 91-92, 105-106.

10 NNo"Prefácio" de sua obra capital, Hans Jonas escreveu: "Prometeu definitivamente desacorrentado, ao qual a ciência confere força antes inimagináveis e a economia 0 impulso infatigável, clama por uma ética..." (JONAS, 2006, p. 21). Hans Jonas, por certo, retirou a expressão — e aditou a ênfase necessária — do título homônimo do poema de Shelley, "Prometheus Unbound: a Lyrical Drama in Four Acts". A propósito, cf. SHELLEY, 2015, p. 60-247. 
Weber, num rasgo de desencanto pela ausência de sentido do fundamento religioso ao mundo contemporâneo ${ }^{11}$, de braços com o ascetismo leigo, asseverara que:

Acima de tudo, este é o summum bonum desta "ética": ganhar dinheiro e sempre mais dinheiro, no mais rigoroso resguardo de todo gozo imediato do dinheiro ganho, algo tão completamente despido de todos os pontos de vista eudemonistas ou mesmo hedonistas e pensado tão exclusivamente como fim em si mesmo, que, em comparação com a "felicidade" do indivíduo ou a sua "utilidade", aparece em todo caso como inteiramente transcendente e simplesmente irracional. O ser humano em função do ganho como finalidade da vida (WEBER, 2004, p. 46).

Pode-se concordar em parte com Weber, pois, talvez seja, praticamente, a quase única finalidade e de horizontes atuais para vida humana, o ganhar dinheiro. Contudo, ainda acerca do movimento de compreensão do elogio crítico do trabalho, tanto sob o modo de produção capitalista, quanto sob o socialista, Thomas Mann, figura destacada da resistência político-cultural ao pan-germanismo hitleriano, anotou nos Tagebücher 1918-21, ao preparar a composição de A Montanha Mágica:

Fiquei pensando, a esse respeito, que a diferença ética entre o capitalismo e o socialismo é insignificante, porque ambos consideram o trabalho o princípio supremo, o absoluto. Não é justo fingir que o capitalismo seja uma forma de vida parasitária e improdutiva. Ao contrário, o mundo burguês não tem conhecido nenhum conceito e valor mais elevado do que o do trabalho, e este princípio ético, que se torna oficial somente no socialismo, vem a ser princípio econômico e critério político e humano, diante do qual somos aprovados ou não, e isto de maneira que ninguém pergunta, por que o trabalho possuiria esta dignidade e santidade absoluta. Ou será que o socialismo traz um novo sentido e uma

11 Sem ceder ao completo desencanto, 0 desencanto de Fernando Pessoa, a passagem abaixo - derivada de reflexão acerca da descrença em toda fé religiosa - pode iluminar e, no mesmo passo, confundir o cenário de acúmulo de tecnociência e de parca produção de valores - mantida a grafia original:

"Ficámos, pois, cada um entregue a si-proprio, na desolação de se sentir viver. Um barco parece ser um objecto cujo fim énavegar; mas o seu fim não é navegar, senão chegar a um porto. Nós encontrámo-nos navegando, sem a idéia do porto a que nos deveriamos acolher. Reproduzimos assim, na especie dolorosa, a formula aventureira dos argonautas: navegar é preciso, viver não é preciso" (PESSOA, 1982, p. 223, aforismo 195). 
nova finalidade ao trabalho? Pelo que eu saiba, não. O trabalho é uma fé, é algo absoluto? Não é. O socialismo não se encontra num nível intelectual, moral, humano e religioso mais alto do que a ideologia burguesa capitalista, sendo apenas um prolongamento desta. É tão ateu quanto ela, pois o trabalho não é divino (T. MANN apud KURZ, 1993, p. 24).

O trabalho, nas atuais condições, embrutece o homem, como embrutecia desde tempos imemoriais até o século XIX e grande parte do século XX, ao tempo em que embrutecia por completo o operário fabril, diga-se, braçal. Em todos os momentos, o trabalho tem sido extremamente alienante. Nos Manuscritos Econômicos-Filosóficos de 1844, Marx conceitua o trabalho como a possibilidade de efetivação da essência humana. Porém, sob o modo de produção capitalista, Marx desvelou o problema e desmontou de ponta a ponta a alienação do homem, sob quatro formas: alienado em relação à natureza; a si próprio; à vida genérica e à humanidade.

Entretanto, deixar de lado a noção marxiana de trabalho abstrato é comparável a voltar à pré-história da humanidade, aos tempos em que os homens não se reconheciam nas suas tentativas de objetivação de conhecimento de si e dos outros. Porém, a situação atual, salvo exagero momentâneo, é semelhante àqueles, pois não é dado reconhecer o homem real sob a aparente racionalidade da administração totalitária do mundo. Sob o arco da vitória do imanentismo do consumo contemporâneo, o trabalho parece que somente tem servido para a conservação do consumo de mercadorias tornadas obsoletas com uma rapidez estonteante. $\mathrm{O}$ consumo é limitado pelo alcance do salário e do sistema de crediário. Contudo, sem que nenhum progresso moral da humanidade esteja à vista. Nem a prazo... Situação diferente da analisada por Veblen, em A Teoria da Classe Ociosa, de 1899, em que escreve que, para

o homem ocioso, o consumo conspícuo de bem valiosos é um instrumento de respeitabilidade. À medida que acumula riqueza, ele é incapaz, sozinho, de demonstrar a própria opulência pelo consumo conspícuo. Recorre por isso ao auxílio de amigos e concorrentes, dando-lhes presentes valiosos e convidando-os para festas e divertimentos dispendiosos. 
Vez que os "divertimentos custosos, tais como potlatch... e o baile, são especialmente próprios para tal fim" (VEBLEN, 1980, p. 51). Para o caso, o consumo ao menos se consumava ${ }^{12}$. Como o crepuscular mundo sob análise vebleniana não existe mais, pois os milionários parecem ter horizontes reduzidos para gozar suas riquezas, merece atenção a "classe $C$ " nacional ao adentrar o universo do consumo não mais pela porta da frente, por motivos óbvios, pois, "acredita-se mais feliz porque, em apoio ao aparente novo ethos de consumo, usa as benesses da indústria do crédito fácil [de entrar, mas não de sair] para não postergar a realização dos desejos;" tomando-se em consideração "a austeridade e o recalque, importantes para a administração do orçamento", como fora no passado "para a própria formação do capitalismo". Uma vez que o "membro da 'classe C' é mobilizado, sistematicamente, a consumir artigos correspondentes ao novo ethos." Resta saber se o "membro da 'classe C' possui um 'eu' suficientemente equipado para dizer não?” (ESTEVES, 2015, p. 57, 62, 87). Pois, consumir em tal patamar social não leva, por certo, a consumar nada ou quase nada.

Se o princípio de realidade parece ter invadido quase todos os poros da individualidade e da vida civil, sobrando muito pouco foro para o princípio de prazer, tal se deu à medida que necessidades falsas e superimpostas foram adicionadas, de modo a subestimar as pessoas e mexer com os instintos violentos do homem. Acaso terão havido outras sociedades, em outros tempos, que viveram com frugalidade, mas em liberdade e sem

12 A propósito, conferir o Capítulo IV, "Consumo Conspícuo", da referida obra de Veblen, p. 48-64. Eis alguns índices: "A discriminação rigorosa no tocante à excelência nos alimentos, na bebida, etc., não somente passa bem logo a determinar a maneira de viver como também a educação e a atividade intelectual do senhor. Ele já não é mais simplesmente 0 homem bem-sucedido e agressivo, 0 homem forte, atilado e intrépido. Ele tem de evitar a deterioração; por isso tem também de cultivar o gosto, já que Ihe é imprescindível discriminar cuidadosamente entre o que é nobre e o que é ignóbil nos bens de consumo. Torna-se ele assim, um connoisseur dos alimentos nobres de vários graus de mérito, das bebidas e dos adornos masculinos, do vestuário adequado, da arquitetura, das armas, dos jogos, das danças e dos narcóticos. Este cultivo do senso estético requer tempo e esforço; portanto, tende ele a transformar a sua vida de ócio num aprendizado mais ou menos árduo para uma vida correta de ócio ostensivo. Estreitamente ligado ao requisito de livre consumo da espécie correta de bens existe um outro requisito; ele deve também saber consumi-los de modo adequado. A sua vida de ócio deve ser corretamente conduzida. Daí 0 aparecimento das boas maneiras... As boas maneiras e os modos de vida refinados são sinais de conformidade com a norma de ócio e de consumo conspícuo" (VEBLEN, 1980, p. 51).

Talvez o precursor do tema saber comportar-se, socialmente, tenha sido Baldassarre Castiglione. Nas páginas de 0 Cortesão, estuda a ambientação de corte, inaugurando o saber comportar-se com elegância para além da mera formalidade da etiqueta, sob talhe neoplatônico e de ares estoico-epicuristas, a par do interesse de Erasmo de Rotterdam pela educação e a etiqueta, à época em que o cosmopolitismo principiara por revolver as antigas formas de sociabilidade.

Rev. Filos., Aurora, Curitiba, v. 30, n. 50, p. 424-449, maio/ago. 2018 
fazer apologia do trabalho pelo trabalho - tendo talvez o elogio da guerra como passatempo? Os homens ditos "primitivos" em nada primitivos, como quer Lévi-Strauss, quiçá podem fornecer munição à querela.

A luta de classes, horror e escândalo da materialidade capitalista, encontra-se diluída, conceitualmente, segundo Kurz, Negri, Habermas. Porém, a despolitização atual encontra-se materializada no emperramento da luta de classes, no esgarçamento da classe operária, no desemprego estrutural, na ausência de horizontes de negação da ordem dada, de par com alimentação envenenada, dissolução familiar, consumo inócuo e venéfico de mercadorias - sem nada consumar, trabalho inútil, megalópoles inumanas e ingovernáveis, prostituição infantil, drogas lícitas e ilícitas, mal-estar na forma de depressão. Porém, o registro mais significativo é o da desigualdade social galopante em todos os quadrantes do mundo. Tempos de barbárie e de desconcertos sociais, a pendular entre o medo e a esperança. Ao mesmo tempo em que, contraditoriamente, operários chegaram à presidência de países secundários da ordem mundial, como a Polônia e o Brasil. O primeiro, sindicalista, empurrado pelo financiamento da CIA e o apoio ideológico de talhe religioso, o segundo, pela virtù construída na luta sindical, de par do carisma inerente ao político - como vocação - , todavia, sem saber conter a má fortuna sempre a rondar. Se o trabalho chegara ao poder, a ordem do capital não fora transformada pela ascensão política de trabalhadores, originados dos chãos do estaleiro e de fábrica.

No caso brasileiro, a despolitização deve-se, em parte, ao sumiço de duas culturas importantes, ambas com clímax e ruína durante o século passado, que foram responsáveis pela formação de quadros políticos universitários engajados e preocupados com o destino político do país. A cultura católica e a comunista foram relevantes, para além do debate estudantil, na intervenção política. A católica, pela formação de quadros instigados pela realização da justiça social, em busca da reforma do capitalismo. A comunista, pela compreensão teórica do lugar do Brasil no contexto mundial desde a entrada em cena do capitalismo hipertardio por essas plagas. Ambas as culturas movidas para a compreensão e a solução de problemas de base da sociedade brasileira, a um tempo em que o Brasil se tornara irreconhecivelmente inteligente. 
De mito, o trabalho firmou-se como "dogma impiedoso", pois figura, modernamente, como "determinação natural do homem", porém, a "própria realidade da sociedade do trabalho desmente este dogma", vez, que os

sacerdotes da religião do trabalho sempre pregaram que o homem, por sua suposta natureza seria um "animal laborans". Somente tornar-se-ia a ser humano na medida em que submetesse, como Prometeu, a matéria natural à sua vontade, realizando-se através de seus produtos. Este mito de explorador do mundo e demiurgo que tem sua vocação desde sempre foi um escárnio em relação ao caráter do processo moderno de trabalho, mas na época dos capitalistas-inventores, do tipo Siemens ou Edison e seus empregados qualificados, tinha ainda um substrato real. Hoje, este gesto é totalmente absurdo (GRUPO KRISIS, 1999, p. 23-24) ${ }^{13}$.

Contudo, a questão basilar da compreensão contemporânea do problema trabalho tem sido, - em parte - , o limite e a condição de expropriação de mais-valia, absoluta ou relativa ${ }^{14}$, que tendeu a transformar as sociedades industriais avançadas da situação de Estado de Bem-Estar Social para a de Estado Beligerante, de modo a preservar o patamar de qualidade de vida social antes alcançado. A propósito, Marcuse, ao perspectivar o pensamento unidimensional e suas consequências, escreveu:

13 "O novo fanatismo do trabalho, com o qual esta sociedade reage perante a morte de seu deus, é a continuação lógica e a etapa final de uma longa história. Desde os dias da Reforma, todas as forças basilares da modernização ocidental pregaram a santidade do trabalho. Principalmente durantes os últimos 150 anos, todas as teorias sociais e correntes políticas estavam possuídas, por assim dizer, pela ideia do trabalho. Socialistas e conservadores, democratas e fascistas combateram-se até a última gota de sangue, mas, apesar de toda a animosidade, sempre levantaram, em conjunto, sacrifícios ao altar do deus-trabalho. 'Afastai os ociosos', dizia o Hino Internacional do Trabalho - e'o trabalho liberta', diziam aterrorizantemente os portões de Auschwitz. As democracias pluralistas do pós-guerra juraram ainda mais a favor da ditadura eterna do trabalho. ...No final do século XX, quase todas as diferenças ideológicas desapareceram. Sobrou o dogma impiedoso, segundo o qual, o trabalho é a determinação natural do homem"(GRUPO KRISIS, 1999, p. 23).

14 Porém, à medida em que a "mudança tecnológica que tende a eliminar a máquina como 'unidade absoluta', parece cancelar a noção marxiana de 'composição orgânica do capital' e, com ela, a teoria da criação da mais-valia" (MARCUSE, 2015, p. 62). Tal advento atrelado à automação dificultaria a medição do trabalho de um proletário individual, diferentemente do que fora observado por Marx ao tempo do modelo de indústria, em que o trabalhador era quase tão somente um trabalhador braçal. Segundo Marcuse, 0"que está em jogo nessas mudanças é algo mais do que um sistema de pagamento, do que a relação de um trabalhador com outras classes e a organização do trabalho. 0 que está em jogo é compatibilidade do progresso técnico com as próprias instituições nas quais a industrialização se desenvolveu" (MARCUSE, 2015, p. 63). Em vista da crise capitalista que se arrasta, as sociedades industriais avançadas têm passado pelo processo desindustrialização da economia, sem eliminar a expropriação da mais-valia. Em muitos casos, trocando desindustrialização pela construção crescente de prisões.

Rev. Filos., Aurora, Curitiba, v. 30, n. 50, p. 424-449, maio/ago. 2018 


\begin{abstract}
"A sociedade da mobilização total, que ganha corpo nas mais avançadas áreas da civilização industrial, combina em produtiva união as características do Estado de Bem-Estar Social (Welfare State) e do Estado de Guerra (Warfare State)" (MARCUSE, 2015, p. 55). Pois,
\end{abstract}

com toda sua racionalidade, o Estado de Bem-Estar Social (WelfareState) é um estado de não-liberdade porque sua total administração é uma restrição sistemática: $a$ ) do tempo livre 'tecnicamente' disponível; $b$ ) da quantidade e da qualidade de bens e serviços 'tecnicamente' disponíveis para atender as necessidades vitais individuais; $c$ ) da inteligência (consciente e inconsciente) capaz de compreender e realizar as possibilidades de autodeterminação (MARCUSE, 2015, p. 78) ${ }^{15}$.

Sob hipótese bastante provável, como efeito colateral em vista dos custos de benefícios sociais relativos ao trabalho nas sociedades industriais avançadas, o sub-operariado chinês tem ocupado aquele lugar antes ocupado pelos trabalhadores norte-americanos e europeus, pelo viés do servilismo oriental e da forma-escravidão contemporânea. Não é de espantar que um sub-operário chinês fuja da China para a Romênia, onde trabalhará em condições iguais ou inferiores a de sua situação anterior, porém, categorizado como operário com alguns direitos. Enquanto isto, um ex-operário romeno trabalha carregando malas no Aeroporto Barajas, de Madrid, por precárias gorjetas. A história das migrações rumo à sobrevivência e ao trabalho é umas das marcas mais cruéis da Modernidade. Compondo parte do tópico, segundo Darcy Ribeiro, o Brasil fora inventado para ser o operariado externo da Europa, desde o início da colonização portuguesa. Caio Prado Jr. alinha-se por esta perspectiva, porém com tintas próprias de interpretação do quadro escravista nacional, sob viés teórico marxiano. Mário de Andrade, no conto "Primeiro de Maio" escrito entre 1934 e 1942, retrata o

15 "Em resumo: as perspectivas de contenção da mudança, oferecidas pela política da racionalidade tecnológica, depende das perspectivas do Estado de Bem-Estar Social (Welfare State). Tal Estado parece capaz de elevar o padrão de vida administrada, uma capacidade inerente a todas as sociedades industriais avançadas em que 0 aparato técnico moderno — erigido como um poder separado e superior aos indivíduos — depende, para seu funcionamento, do desenvolvimento e expansão intensificados da produtividade. Sob tais condições, o declínio da liberdade e da oposição não é uma questão de deterioração ou de corrupção moral ou intelectual. É antes um processo social objetivo na medida em que a produção e a distribuição de uma quantidade crescente de bens e serviços estão de acordo com uma atitude tecnológica racional" (MARCUSE, 2015, p. 78). 
desconforto do personagem “35”, carregador de malas da Estação da Luz, na cidade macota de São Paulo, que, de início entusiasmado com o desejo de que "não carregava mala de ninguém, havia de celebrar o dia deles. E agora tinha um grande dia pela frente". Ao final do dia e do conto, depois de tantos desencontros e da crescente dificuldade de encontrar sentido no perambular pelo centro da cidade, volta à Estação da Luz para ajudar o "22", colega velhote, a carregar "duas malas maiores, que ergueu numa só mão, num esforço satisfeito de músculos". $\mathrm{O}$ " 35 " não conseguira descolar-se do cotidiano repetitivo de trabalho alienado (ANDRADE, 1979, p. 35, 48).

Marcuse, na obra magna O Homem Unidimensional, de 1964, escreveu que, por certo, "o trabalho deve preceder a redução do trabalho e a industrialização deve preceder o desenvolvimento das necessidades e satisfações humanas". Todavia, prossegue Marcuse, a "mais alta produtividade do trabalho pode ser usada para a perpetuação do trabalho e a mais eficiente industrialização pode servir para a restrição e a manipulação das necessidades" (MARCUSE, 2015, p. 54). Contudo, em Eros e Civilização, de 1955, Marcuse levanta a hipótese direcionada à sociedade industrial avançada de troca da força do conhecimento transformador da natureza e da vida humana trazida por Prometeus, redivivo, pela civilização libidinal a ser promovida através da força da sensualidade de Eros. O centro da discussão deriva da concepção dos nexos entre civilização e repressão, a tese de Freud, como sendo impossível haver civilização sem repressão das pulsões. Marcuse advoga a possibilidade de uma civilização não repressiva a começar pelo questionamento da forma atual do trabalho alienado, sob a qual, praticamente, todos se encontram.

Marcuse, em O Homem Unidimensional, questiona a premissa marxiana acerca das condicionantes da alienação, ao momento em que o alienado aceita a alienação, como o ocorrido frente às aparentes vantagens da sujeição na sociedade industrial avançada. Permutar Prometeus por Eros quiçá seja a questão basilar da civilização tecnológica, sob a fina compreensão de Marcuse, a rigor o novo homem livre será um tipo de artista, de poeta, de sábio, na forma de um novo herói, o herói cultural para além das amarras do trabalho alienado e alienante, sem fim, pela aparência. O capítulo intitulado "As imagens de Orfeu e Narciso" reflete acerca dos novos arquétipos de uma existência humana - futura - não 
repressiva, desde o cenário de contraposição da parceria de Narciso e de Orfeu a Prometeus. O ponto de inflexão aparece ao tratar da luta mítica de Eros contra duas tiranias: da racionalidade e da morte. O resultado da proposta utópica será a reconciliação do homem com a natureza, sob o arco de uma civilização libidinal (MARCUSE, 1975, p. 146-155) ${ }^{16}$.

No Brasil, o horizonte utópico da sociedade libidinal, avant la lettre, surgiu da proposta oswaldiana de civilização contida no Manifesto Antropófago, que, tempos depois, foi assimilada, no detalhe, e estendida ao ponto máximo de tensão pela intervenção tropicalista, através da música, do cinema, do teatro, das artes plásticas. Heróis culturais da gesta tropicalista estiveram em movimento para descongestionar os antagonismos repressivos e, sobremaneira, os regressivos. O horizonte revolucionário libidinal apresentara-se com potencialidade de revolver os traumas residuais da cultura brasileira e, quiçá, criar, antes mesmo da invenção conceitual, uma cultura libidinal, autóctone. Eis uma tarefa política das mais urgentes do ponto de vista da cultura, que de carona, forçosamente, colocará em questão o trabalho alienado, alienante. Afinal como escreveu Oswald de Andrade: "Contra a realidade social, vestida e opressora, cadastrada por Freud - a realidade sem complexos, sem loucura, sem prostituições e sem penitenciárias do matriarcado de Pindorama”" (ANDRADE, 1967, p. 103). De par com a tirada excelente de Mário de Andrade em defesa da "divina preguiça", talvez o delta inicial da solução do problema do trabalho, ao menos em solo pátrio.

${ }^{16}$ A expressão "civilização libidinal"é a hipótese demarcada por Marcuse em Eros e Civilização. Entretanto, no Ensaio sobre a Libertação, passa a utilizar a expressão "ethos estético", pois, a escassez, o trabalho alienado, a mais-repressão e o princípio de desempenho seriam vencidos, com o auxílio da reorientação do progresso e da tecnologia, para edificação de uma civilização erótica/livre, fundada na "pacificação da existência" e na beleza. 0 "ethos estético" seria o princípio de realidade (libidinoso), que superaria o princípio de desempenho. É tal articulação conceitual que Marcuse pensa a partir da segunda metade da década de 1960, ao ser menos pessimista, se comparado com o pensamento de 0 homem unidimensional em relação ao futuro. Trata-se de um alvitre, que reforça a luta contra a cada vez mais desnecessária labuta diária e a ideologia de sustentação do trabalho. Porém, sociologicamente, há que se mostrar como será possível viabilizar esta outra nova ordem. André Gorz e Richard Sennet aventuraram-se por este caminho. Esta nota resulta de conversas marcusianas com Anderson Alves Esteves, pelo que muito agradeço. Talvez seja possível conciliar a perspectiva marcusiana da sociedade organizada desde a civilização libidinal com a de Ernst Bloch, que opera sob outro recorte, 0 do horizonte da docta spes. 
Os versos de Fernando Pessoa, sob a figura heterônima de Álvaro de Campos, projetam a possibilidade de aplicação poética do saber ciceroniano, contido na máxima "mais trabalho quando não faço nada". Ei-los:

[458] "Aproveitar o tempo! Mas o que é o tempo, que eu o aproveite?

Aproveitar o tempo! Nenhum dia sem linhas... O trabalho honesto e superior... O trabalho à Virgílio, à Mílton... ${ }^{17}$ Mas é tão difícil ser honesto ou superior! É tão pouco provável ser Mílton ou ser Virgílio!

Aproveitar o tempo! Ah, deixem-me não aproveitar nada! Nem tempo, nem ser, nem memórias de tempo ou de ser!" (Álvaro de Campos, "Apostila", Ficções de Interlúdio. In: PESSOA, 1986, p. 366-367)

De outra forma, vale a da sabedoria da cultura popular sintetizada na expressão do ex-servente de pedreiro e campeão lutador de box, Sr. Adilson “Maguila" Rodrigues: “o trabalho danifica o homem!". Porém, a pilhéria não resolve nem altera a maldade humana, registrada e realizada na sentença de morte fixada no pórtico de Auschwitz: "Arbeitmacht frei".

O fato mais importante da História do Brasil é, sem titubeio, a abolição da escravatura. Mas, o que ocorreu após? Os escravos não foram assimilados de modo adequado, honesto e justo à sociedade, nem puderam explicitar politicamente os seus direitos de novos cidadãos, logo transformados em abandonados sociais. Nem puderam voltar à condição anterior, pois como registrou Gilberto Freyre, a situação social do escravo brasileiro na segunda metade do século XIX era superior, em qualidade, a dos operários europeus, no mesmo período. Consideração que carece da devida prospecção. Em tempo anterior, em 1807, Hegel refletira

17 As"crases" constam do texto original. 
acerca da dialética do senhor e do escravo nas páginas da Fenomenologia do Espírito, com resolução de viés estoico, a da liberdade interior ${ }^{18}$. Pois,

[...]se a liberdade nada mais é do que a completa autossuficiência, se tudo o que não é inteiramente meu, ou que não sou eu, restringe minha liberdade, então a liberdade só pode realizar-se no pensamento. Era pois de se esperar que Hegel considerasse o estoicismo como a primeira forma histórica da autoconsciência (MARCUSE, 1978, p. 119).

Se a casa-grande desfez a senzala numa parente passe de mágica, o hino à República, produzido em 1890, desfazia, literariamente, o passado escravocrata: "Nós nem cremos que escravos outrora / Tenha havido em tão nobre país!" (SCHWARTZ, janeiro 1973, p. 158). Outrora, dois anos antes, 1888. O hino atrela-se ao ato polêmico do ministro Ruy Barbosa, que mandara queimar os autos do tráfico negreiro para o Brasil ${ }^{19}$.

18 Marcuse escreveu: “Hegel desenvolveu a relação entre a condição de senhor e a de escravo como uma relação em que cada um dos termos reconhece que tem sua essência no outro, e que só atinge sua verdade pelo outro" (MARCUSE, 1978, p. 118). Max Stirner acompanhou os cursos de Hegel, tanto o que redundou na escrita da Fenomenologia do Espírito quanto o da Introdução à Filosofia do Direito. A propósito, para Miranda: "Sendo certo que Stirner não cita Hobbes, embora se refira à 'guerra de todos contra todos', santo-e-senha do hobbesianismo, que ele lê à luz da famosa dialéctica do senhor e do servo que Hegel apresenta na Fenomenologia do Espírito como a linha vermelha que costura a cultura ocidental. 0 fim da história equivalia, para Hegel, ao fim dessa dialéctica de servidão de cuja abolição emerge o 'reino da liberdade', que se concretiza no Estado de Direito" (MIRANDA, 2004, p. 303). Resta saber de onde veio a inspiração hegeliana para invenção da dialética senhor-escravo! Acaso teria sido da independência do Haiti de par com a suspensão inglesa do tráfico negreiro? Que ocorreram por volta de 1807, ao mesmo tempo da escrita da Fenomenologia do Espírito.

19 A questão é controversa. Francisco de Assis Barbosa, na "Apresentação do livro Rui Barbosa e queima dos arquivos", escreve: "IRREFLEXÃO, LEVIANDADE OU ALEIVOSIA - EIS 0 TRÍPTICO da malévola e reiterada acusação a Rui Barbosa em torno dos arquivos da escravidão, que de resto jamais existiram. 0 ato que mandou queimar todos os papéis, livros de matrícula e documentos relativos a escravos nas repartições do Ministério da Fazenda teve por finalidade eliminar os comprovantes de natureza fiscal que pudessem ser utilizados pelos ex-senhores para pleitear a indenização junto ao governo da República, já que a Lei de 13 de Maio de 1888 havia declarado extinta a escravidão, sem reconhecer 0 direito de propriedade servil. Nem poderia fazê-lo. 0 próprio Rui Barbosa, dissertando a respeito, deixara bem claro esse ponto, ao relatar o projeto da emancipação do elemento servil em 1884: '0 princípio da indenização ficara repudiado para sempre, e rotos com ele os famosos títulos de senhorio da raça branca sobre a negra. Essa intuição iluminou em um relâmpago 0 futuro, e travou a pugna entre o ódio e a esperança.' Assim, 0 ato de Rui Barbosa deve ser examinado à luz da mentalidade da época e das circunstâncias políticas que o cercaram, sem o que não estaríamos fazendo história" (BARBOSA, F. A., Apresentação ao livro Rui Barbosa e a Queima dos Arquivos. In: LACOMBE; SILVA; BARBOSA, 1988, p. 11-12. Disponível em: $<$ http://www.casaruibarbosa.gov.br/dados/DOC/artigos/a-j/FCRB_FranciscodeAssisBarbosa_Apresentacao_livro_ RuiBarbosa_queima_arquivos.pdf $>$. Acesso em: 20 jan. 2018).

Rev. Filos., Aurora, Curitiba, v. 30, n. 50, p. 424-449, maio/ago. 2018 
No Brasil, a novidade do "todos quererem trabalhar", em contraponto à vida boêmia e à malandragem, atingidas pelas expressões pejorativas como "vagabundo", "desocupado" e "preguiçoso", vem dos tempos do Estado Novo. Getúlio Vargas orientara o DIP a arregimentar compositores populares a produzirem canções estimulantes da vontade de trabalhar, para além dos impenetráveis discursos moralizantes, de par com as vantagens econômicas e sociais do processo de industrialização brasileira, em curso desde os anos 30, do século passado. Vários sambas foram compostos sob tal orientação. Em 1941, Ataulfo Alves e Wilson Batista compuseram a canção carnavalesca "Bonde de São Januário", cantada por Ciro Monteiro. A alusão à locomoção dos operários do tradicional bairro operário carioca servia de mote ao elogio do trabalho:

Quem trabalha é que tem razão / eu digo e não tenho medo de errar. / O bonde de São Januário leva mais um operário / sou eu que vou trabalhar. // Antigamente eu não tinha juízo / Mas resolvi garantir meu futuro. / Vejam vocês: / Sou feliz / Vivo muito bem / A boêmia não dá camisa a ninguém. / E digo bem.

A inevitável paródia ocorreu por conta da troca de "operário" por "otário". A conversão de Wilson Batista é notável, pois em 1933, esteve convencido que o trabalho não era a melhor solução para a vida, compôs o hino da malandragem "Lenço no pescoço", cantado por Silvio Caldas:

Meu chapéu do lado/ Tamanco arrastando/ Lenço no pescoço/ Navalha no bolso/ Eu passo gingando/ Provoco e desafio/ Eu tenho orgulho / Em ser tão vadio. / Sei que eles falam/Deste meu proceder/ Eu vejo quem trabalha/Andar nomiserê/ Eu sou vadio/ Porque tive inclinação/ Eu me lembro, era criança/ Tirava samba-canção/ (Comigo não/ Eu quero ver quem tem razão) [...].

Chico Buarque, na canção "Tem mais samba", traz um verso na linha do elogio crítico do trabalho: "Tem mais samba no homem que trabalha". No mesmo passo, em 1973, compôs o samba "Vai trabalhar, vagabundo", para o filme homônimo de Hugo Carvana, desmitificando a idealização do trabalho árduo de par com a desgraça do pobre honesto. Tempos depois, frente à racionalização de trabalho sob os ares nacionalistas da ditadura militar-empresarial, compôs a "Homenagem ao Malandro" a retratar a 
nova situação: "Mas o malandro pra valer / Não espalha / Aposentou a navalha / Tem mulher e filho e tralha e tal / Dizem as más línguas que ele até trabalha / Mora lá longe e chacoalha / Num trem da Central".

O que fazer do ponto de vista político? Esgotados os limites flácidos da democracia representativa, participativa, resta a experiência rediviva dos conselhos, da autogestão social e pedagógica como a forma política de organização - sem partidos e sem políticos profissionais -, que ousa apontar para a explicitação do conflito natural político, descoberto pelos romanos antigos e redivivo por Maquiavel, nos Discorsi. Uma vez que além da participação popular autêntica na contramão das manipulações das agências de opinião pública, dos meios de comunicação de massa, das agências de publicidade, do empresariado a comprar políticos no mercado de sucatas de vereadores, deputados, senadores, prefeitos, governadores, presidentes, sempre e cada vez menos valorizados na forma-mercadoria pelo preço de custo e de pagamentos, ou somente alugados, ou terceirizados, dada a volatilidade do mercado político. $\mathrm{O}$ antídoto eficaz pode ser a velha nova forma da autogestão em todos os níveis de organização social, na linha da horizontalidade, sem Judas como representantes antipovo, sem populismo, tão ao gosto da tradição latino-americana. Sem profetas de nenhuma ordem. Sem heróis construídos e indigestos, sem vítimas... Afinal, se for impossível liquidar o trabalho, - o que dará muito trabalho - , que seja ao menos possível organizar o trabalho desde o trabalho - pelos trabalhadores -, não mais pelo capital. De modo autogestionário, a realizar o homo ludens latente em todos os homens. Pois o jogo, qualquer jogo desde que não entre dinheiro nas apostas, tem regras éticas fundamentais para a formação do homem². - Eis um possível aspecto da fórmula docta spes.

20 Para Maria Helena Soares de Souza: “Segundo Huizinga, o jogo é mais antigo que a cultura, pois os animais também jogam, respeitando regras. [...] 0 jogo é uma atividade estruturalmente livre, pois é voluntário, em geral, joga-se por gosto; pode ser adiado, suspenso, retomado; é desinteressado, já que não faz parte da vida comum; é temporário, limitado por tempo, espaço e regras. Por todos os motivos, não amarra. No jogo reina uma ordem absoluta e específica. 0 jogo na verdade cria a ordem e os jogadores devem respeitá-la." Prossegue afirmando que "Em amplo sentido, há um forte fator estético no jogo, 0 que traz fascinação. A beleza encontra espaço de expressão nas peças, tabuleiros, quadras, uniformes, torcidas." Pois o jogo "é não-seriedade, o que não quer dizer que ele não seja sério. Alguns jogos são jogados com extrema seriedade, inclusive pelas crianças." Ressalta também, outra característica do jogo que é "a existência de uma tensão impulsionante que leva à mobilização dos códigos éticos: no desejo de ganhar ou acabar antes são postas à prova a coragem, as habilidades, como a 
O problema de base da conexão e, ao mesmo tempo, da disjunção entre ética e trabalho, na Modernidade, será somente tangenciado, se não tratar da expropriação da mais valia: o tempo de trabalho expropriado da força de trabalho, esforço físico e mental despendido, necessário no processo de produção, efetivamente realizado. Ao tratar da avidez pelo trabalho excedente, Marx ilustra-o com a morte da modista Mary Anne Walkley ${ }^{21}$, de 20 anos, ocorrida em junho de 1863, na cidade de Londres, por excesso de horas de trabalho ininterruptas, ao todo 26 horas e meia. Marx analisa também os infortúnios do trabalho dos ferreiros, que por excesso de trabalho tendiam a morrer aos 37 anos e não aos 50 anos como esperado. A propósito Marx escreveu: “Os meios de produção, o capital constante, só existem, do ponto de vista da proporcional de trabalho excedente" (MARX, I, 1975, p. 290). Logo, será preciso liquidar com o fetiche do trabalho ou ao menos ressignificá-lo ${ }^{22}$.

inteligência e a astúcia: a lealdade — mesmo querendo ganhar, o jogador sabe que há regras a serem observadas". SOUZA, 2007, p. 127, 129. A título de acréscimo ao tema, conferir também URTASUN, A. Homo Ludens. El artista frente al juego. In: URTASUN; MORAZA; DEL CAMP0, 2011, p. 13-112.

21 "Nas últimas semanas de junho de 1863, todos os jornais de Londres traziam uma notícia encimada com um título sensacional: 'Morte por excesso de trabalho'. Trata-se da morte da modista Mary Anne Walkley, de 20 anos, que trabalhava numa renomada casa de modas, explorada por uma senhora com 0 agradável nome de Elisa. A velha história tantas vezes contada foi de novo descoberta: moças que trabalham ininterruptamente $16 \frac{1}{2}$ horas, durante a temporada às vezes 30 horas consecutivas, sendo reanimadas, quando fraquejam, por meio de xerez, vinho do porto ou café. Estava-se então no auge da temporada. Era necessário concluir, como num passe de mágica, os vestuários luxuosos das damas da nobreza convidadas para 0 baile em homenagem à princesa de Gales, recentemente importada. Mary Anne Walkley tinha trabalhado 26 1⁄2 sem interrupção, juntamente com 60 outras moças. Elas formavam grupos, ficando cada grupo de 30 num aposento cuja capacidade cúbica mal chegava para conter 0 ar necessário para elas. À noite, elas se revezavam duas a duas numa cama que ficava dentro de um dos cubículos de madeira em que se dividia o quarto de dormir. Eesta era uma das melhores casas de Londres. Mary Anne Walkley adoeceu na sexta-feira e morreu no sábado, sem antes ter terminado sua última tarefa, para surpresa da Sra. Elisa. 0 médico chamado tarde demais à cabeceira da moribunda, Dr. Keys, testemunhou laconicamente perante o júri de instrução:

'MARY ANNE WALKLEY MORREU POR TER TRABALHADO EM EXCESSO NUM QUARTO SUPERLOTADO E DORMINDO NUM CUBÍCULO MAL VENTILADO'.

Para dar ao médico uma lição de boas maneiras, declarou o júri de instrução:'A vítima morreu de apoplexia, mas há motivos para se recear que o trabalho em excesso numa oficina superlotada apressou sua morte etc.'

Nossos 'escravos brancos', bradou o Morning Star, órgão dos livre-cambistas Cobden e Bright,'nossos escravos brancos são levados ao túmulo por estafa e fenecem e morrem silenciosamente'"'(MARX, 1975, p. 287-289).

22 "Marx é tido geralmente como o teórico do trabalho, e aí reside um engano, que não deturpa inteiramente o programa do teórico de Triers, mas o desvia ligeiramente. Marx, na verdade, é o teórico da mercadoria e do capital." OLIVEIRA, F. Que preguiça! 0 fetiche do trabalho. In: NOVAES, 2012, p. 481. - Oliveira parece esquecer que o capital é trabalho coagulado. Assim, Marx tratara, fundamentalmente, do trabalho em 0 Capital.

Rev. Filos., Aurora, Curitiba, v. 30, n. 50, p. 424-449, maio/ago. 2018 
Que ética do trabalho, calcada em costumes considerados, - não qualquer costume, bem entendido - , resiste a tal identificação conceitual materialista? Revivida pelos trabalhadores intelectuais da atualidade, no exercício excessivo de horas de trabalho nos ambientes acadêmicos ou corporativos, - mesmo sob a expropriação da mais-valia relativa - , a exceder ou a empatar com o número de horas de trabalho dos operários de meados do século XIX, na Inglaterra! Encarnando de modo antecipado a figura contemporânea do workaholic. O filósofo sul-coreano Byung-Chul Han desconfia da fórmula, pois afinal a pessoa em verdade explora a si mesma, imaginando que deste modo pode vir a realizar-se na sociedade do hiperconsumismo.

Contudo, entre o moderno flanar, ícone da pessoa desocupada por viver de rendas, atualizado pelo rentismo, e o atualíssimo surfar na internet, surge uma nova categoria de trabalhadores domésticos, a dos cybertariat, que, segundo Ursula Huws, poderá substituir a inadequada denominação lumpenproletariat, a dos trabalhadores avulsos, que sobreviviam sem emprego fixo, de expedientes, de "bicos". Houve filósofo, com razão, que lançasse sobre estes últimos a esperança - em nome dos desesperançados - de uma libertação, pois não estariam comprometidos com a (ir)racionalidade administrativa capitalista. Momentaneamente, a ordem racional e o mercado se impuseram de modo hegemônico. Ocorre que o mercado organiza a sociedade, mas não cria valores éticos fortes, que tendam à universalidade e à negação da ordem em curso.

A invenção do descarte do operário envelhecido e sem músculos para o trabalho braçal foi obra de Bismark, no Século XIX. Aquele trabalhador que não servisse mais para o trabalho deveria ir, literalmente, para os aposentos, de modo a ceder lugar ao jovem musculoso nas tarefas de trabalho fabril. Afinal, é de onde deriva o termo aposentadoria? Trata-se de sinônimo de ir para os aposentos, que na maioria dos casos deve ser acompanhada de pensão destinada à precária sobrevivência.

Urge reinventar o ócio. $\mathrm{O}$ ócio compreendido como exercício de admiração desinteressada, desfrute, deleite, preguiça, impulso à quebra da representação social em meio à tensão agonal diária dos coros da tragédia em disputa verbal, rediviva no ambiente de trabalho. Ao contrário do lazer, como a reposição de energias, analisado e incensado por sociólogos do trabalho. O ócio autêntico é aquele pautado pelo tempo verdadeiramente 
livre. Tempo livre para não fazer nada, nada que não seja poesia, cultivo da amizade, do apropriar-se de si mesmo, a la Stirner. Sem ócio autêntico e real, o que fazer? Reitera-se o consumir mercadorias, tornadas obsoletas numa rapidez estonteante, na linha das falsas necessidades superimpostas. Porém, consumir sem que nada se consuma, no embalo da voracidade do consumo, desde o consumo da natureza até a sua destruição. Sob o arco da vitória do imanentismo contemporâneo, trabalhar destina-se quase tão somente ao ato de consumir bens e serviços, como falsas necessidades. Qual a vantagem deste circuito estupefaciente para o progresso moral da humanidade? Se é que a interrogação persiste com propriedade e sentido. Enquanto a questão movimenta-se para pautar o debate acerca do trabalho, é preciso reinventar o ócio, para além dos pressupostos do direito à preguiça, a la Paul Lafargue. Quiçá, como o ensaiado na forma do ócio artístico, em A Farsa da Boa Preguiça, de Ariano Suassuna, escrita em 1960.

Ocorre que o mundo está fora dos eixos - o mundo, que gerou a premissa do lavoro, ergo sum. Assim, o arremate dos males do passado e do presente surge na forma de um se condicional: se Sísifo é superior ao seu destino, cumpre imaginar Sísifo - o herói absurdo - feliz! ${ }^{23}$

\section{Referências}

ANDRADE, M. Contos Novos. 9. ed. São Paulo: Martins, 1979.

ANDRADE O. Manifesto Antropófago. In: ANDRADE, O. Trechos Escolhidos, organizados por Haroldo de Campos. Rio de Janeiro: Agir, 1967.

BACON, F. Novum Organum ou verdadeiras indicações acerca da Interpretação da Natureza. 2. ed. Trad. José Aluysio Reis de Andrade. São Paulo: Abril Cultural, 1979. (Coleção “Os Pensadores”).

23 "Deixo Sísifo no sopé da montanha! Encontramos sempre o nosso fardo. Mas Sísifo ensina a fidelidade superior que nega os deuses e levanta os rochedos. Ele também julga que tudo está bem. Esse universo enfim sem dono não lhe parece estéril nem fútil. Cada grão dessa pedra, cada estilhaço mineral dessa montanha cheia de noite, forma por si só um mundo. A própria luta para atingir os píncaros basta para encher um coração de homem" (CAMUS, 2008, p. 116). 
BARON, H. En busca del humanismo civico florentino. Ensayos sobre el cambio del pensamiento medieval al moderno. Trad. Miguel Abelardo Camacho Ocampo. México: Fondo de Cultura Económica, 1993.

BLACK, B. La Abolición del Trabajo. Trad. Julius Van Daal. Logroño (Rioja): Pepitas de Calabaza, 2013.

CAMUS, A. Le mythe de Sisyphe: essai sur l'absurde. Paris: Gallimard, 2008.

CAMUS, A. O Mito de Sísifo: ensaio sobre o Absurdo. Trad. Urbano Tavares Rodrigues. Lisboa: Livros do Brasil, 1942.

ESTEVES, A. A. A “Classe C" vai ao Paraíso? A Estratificação Social do Brasil no início do século XXI. Saarbrücken: Novas Edições Acadêmicas, 2015.

GIACOIA JUNIOR, O. Nietzsche: o humano como memória e como promessa. 2. ed. Petrópolis: Vozes, 2013.

GRUPO KRISIS. Manifesto contra o Trabalho. Trad. Heinz Dieter Heidemann e Claudio Duarte. São Paulo: GeoUSP / LABUR, julho de 1999. (Cadernos do LABUR, n. 2).

HESÍODO. Los Trabajos y los Días. Introd., vers. rítmica, notas: Paola Vianello de Córdova. México: Universidad Nacional Autónoma de México, 2007.

HOLANDA, S. B. Raízes do Brasil. São Paulo: Cia. das Letras, 2006.

JONAS, H. O Princípio Responsabilidade: ensaio de uma ética para a civilização tecnológica. Trad. Marijane Lisboa e Luiz Barros Montez. Rio de Janeiro: Contraponto; Editora PUC Rio, 2006.

LACOMBE, A. J.; SILVA, E.; ASSIS BARBOSA, F. Rui Barbosa e a Queima dos Arquivos. Brasília: Ministério da Justiça; Rio de Janeiro: Fundação Casa de Rui Barbosa, 1988. Disponível em: <http://www.casaruibarbosa.gov.br>. Acesso em: 13 ago 2016.

LAFARGUE, P. O Direito à Preguiça. Trad. J. Teixeira Coelho Netto. São Paulo: Kairós, 1980.

LEOPARDI, G. Giacomo Leopardi - poesia e prosa. Org., notas: Marco Luchesi. Rio de Janeiro: Nova Aguilar, 1996. 
LEOPARDI, G., Zibaldone di Pensieri. A cura de Fabiana Cacciapuoti. Roma: Donzelli, 2014.

KURZ, R. O Colapso da Modernização: da derrocada do socialismo de caserna à crise da economia mundial. 2. ed. Trad. Karen Elsabe Barbosa. Rio de Janeiro: Paz e Terra, 1993.

MARCUSE, H. O Homem Unidimensional: estudos da ideologia da sociedade avançada. Trad. Robespierre de Oliveira, Deborah Christina Antunes, Rafael Cordeiro Silva. São Paulo: Edipro, 2015.

MARCUSE, H. Eros e Civilização: uma interpretação filosófica do pensamento de Freud. 6. ed. Trad. Álvaro Cabral. Rio de Janeiro: Zahar, 1975.

MARCUSE, H. Cultura e Sociedade. Trad. Wolfgang Leo Maar, Isabel Maria Loureiro, Robespierre de Oliveira. Rio de Janeiro: Paz e Terra, 1998. v. II.

MARCUSE, H. Razão e Revolução: Hegel e o advento da teoria social. 2. ed. Trad. Marília Barroso. Rio de Janeiro: Zahar, 1978.

MARX, K. O Capital. Crítica da Economia Política. Trad. Reginaldo Sant'Anna. Rio de Janeiro: Civilização Brasileira, 1975. Livro I: O Processo de Produção de Capital, v. I

MARX, K. Manuscritos Econômico-Filosóficos. Trad. Jesus Ranieri. São Paulo: Boitempo, 1844/2006.

MIRANDA, J. A. B. Stirner, o passageiro clandestino da história. In: STIRNER, M. O único e a sua Propriedade. Trad. João Barrento. Lisboa: Antígona, 2004. p. 295-339.

NIETZSCHE, F. Aurora (Reflexões sobre os preconceitos morais). Trad. Mario D. Ferreira dos Santos. São Paulo: Sagitário, 1947. (Coleção “Climax” I).

NOVAES, A. (Org.). Ética. São Paulo: Cia. das Letras/Secretaria Municipal de Cultura, 1992.

NOVAES, A. (Org.). Mutações: elogio à preguiça. São Paulo: SESC SP, 2012.

PESSOA, F. (sob heterônimo de Bernardo Soares). Livro do Desassossego. Org. Jacinto do Prado Coelho. Lisboa: Ática, 1982. v. I.

PESSOA, F. Obra Poética. Rio de Janeiro: Nova Aguilar, 1986. 
SHELLEY, P. Prometeu Desacorrentado e outros poemas. Trad. Adriano Scandolara. Belo Horizonte: Autêntica, 2015. (Edição bilíngue).

SENNET, R. A Corrosão do Caráter: consequências pessoais do trabalho no novo capitalismo. Trad. Marcos Santarrita. Rio de Janeiro: Record, 1999.

SMITH, A. Investigação sobre a Natureza e as Causas da Riqueza das Nações. Trad. Conceição Jardim Maria do Carmo Cary, Eduardo Lúcio Nogueira. São Paulo: Abril Cultural, 1974. (Coleção "Os Pensadores").

SOUZA, M. H. S. Jogos Pedagógicos em Matemática no Ensino Médio: mais que motivação, metodologia. Tese (Doutorado em Educação-Currículo) - Pontifícia Universidade Católica de São Paulo, São Paulo, 2007.

TEIXEIRA, F. R. Fim do Ethos antigo e ocaso das ilusões: Giacomo Leopardi e a modernidade. Tese (Doutorado em Filosofia) - Universidade de São Paulo, São Paulo, 2013.

URTASUN, A.; MORAZA, J. L.; DEL CAMPO, J. G., Homo Ludens: el artista frente al juego. Artista jolasaren aurrean. Navarra: Jorge Oteiza, 2011. (Edición Trilingüe).

VALVERDE, A. J. R. Aportes a Oratio Hominis Dignitate, de Pico della Mirandola. Revista de Filosofia Aurora, Curitiba, v. 21, n. 29, p. 457-480, jul./dez. 2009.

VEBLEN, T. A Teoria da Classe Ociosa. Trad. Olívia Krähenbühl. 2. ed. São Paulo: Abril Cultural, 1980. (Coleção “Os Pensadores”).

WEBER, M. A Ética Protestante e o "Espírito" do Capitalismo. Ed. A. F. Pierucci. Trad. José Marcos Mariani de Macedo. São Paulo: Cia. das Letras, 2004.

Recebido: 08/03/2018

Received: 03/08/2018

Aprovado: 21/06/2018

Approved: 06/21/2018 